\title{
IMPROVEMENTS IN MANUFACTURE OF IRIDIUM ALLOY MATERIALS
}

\author{
Evan K. Ohriner \\ Metals and Ceramics Division \\ Oak Ridge National Laboratory \\ P.O. Box 2008 \\ Oak Ridge, Tennessee 37831 \\ (615) $574-8519$
}

CONF-930103--2

DE92 017126

\section{Abstract}

Iridium alloys are used as fuel-cladding material in radioisotope thermoelectric generators (RTGs). Hardware produced at the Oak Ridge National Laboratory (ORNL) has been used in Voyager 1 and 2, Galileo, and Ulysses spacecraft. This hardware was fabricated from small, 500-g drop-cast ingots. Porosity in these ingots and the resulting defects in the rolled sheets caused rejection of about $30 \%$ of the product. An improved manufacturing process was developed with the goal of substantially reducing the level of defects in the rolled sheets. The ingot size is increased to $10 \mathrm{~kg}$ and is produced by vacuum arc remelting. In addition, the ingot is hot extruded prior to rolling. Since implementation of the process in 1989, the average rate of rejection of the product has been reduced to below $10 \%$.

\section{INTRODUCTION}

Radioisotope thermoelectric generators convert heat of radioactive decay to electrical energy for use in spacecraft. The fuel in the form of 238 plutonium-dioxide pellets is encapsulated in a DOP-26 iridium alloy cladding. The alloy containing 2000- to 4000-ppm tungsten, 30- to $90-\mathrm{ppm}$ thorium, and 20- to 80 -ppm aluminum by weight is produced at the Oak Ridge National Laboratory (ORNL) in the form of $52-\mathrm{mm}$-diam by $0.64-\mathrm{mm}$-thick circular blanks which are formed into cups, pairs of which are welded together, to encapsulate the fuel.

The production of blanks for the Galileo and Ulysses spacecraft, during the period 1981 to 1984 , as well as the earlier production for the Voyager spacecraft, employed laboratoryscale methods of alloy processing (Braski and Schaffhauser 1975). Small ingots of about $500 \mathrm{~g}$ were arc melted, drop cast, and rolled to sheet from which blanks were machined. The small ingots contained shrinkage porosity, which was not closed during the subsequent rolling operation, and appeared as laminar defects in the ground blanks. This resulted in relatively high rates of rejection of blanks for ultrasonic and dye-penetrant indications. In order to improve the product yield and decrease the production costs, an improved manufacturing process was developed and qualified for the production of blanks for the Cassini spacecraft.

\section{MANUFACTURING PROCESS DESCRIPTION}

The manufacturing process is summarized schematically in Figure 1. Purchased iridium powder is sampled, chemically analyzed, and blended with tungsten powder to produce the Ir- $0.3 \% \mathrm{~W}$ composition. The blended powder is compacted without a binder, hydrogen annealed, and vacuum sintered. The sintered compacts are electron-beam (EB) melted multiple times to produce alloy buttons of about $500 \mathrm{~g}$. The EB melting, performed in high vacuum $\left(<10^{-3} \mathrm{~Pa}\right)$, causes vaporization of many of the impurities in the starting powders as well as significant quantity of iridium itself. Final alloying with thorium and aluminum, 


\section{DISCLAIMER}

This report was prepared as an account of work sponsored by an agency of the United States Government. Neither the United States Government nor any agency Thereof, nor any of their employees, makes any warranty, express or implied, or assumes any legal liability or responsibility for the accuracy, completeness, or usefulness of any information, apparatus, product, or process disclosed, or represents that its use would not infringe privately owned rights. Reference herein to any specific commercial product, process, or service by trade name, trademark, manufacturer, or otherwise does not necessarily constitute or imply its endorsement, recommendation, or favoring by the United States Government or any agency thereof. The views and opinions of authors expressed herein do not necessarily state or reflect those of the United States Government or any agency thereof. 


\section{DISCLAIMER}

Portions of this document may be illegible in electronic image products. Images are produced from the best available original document. 
in the form of master alloys, is performed by button-arc melting with a tungsten electrode under a partial pressure of argon in order to minimize vaporization of aluminum from the melt. The above steps are identical for both processes.

In the previously used production process, the alloy button was arc melted in a watercooled copper hearth and then allowed to drop through a hole in the bottom of the hearth into a rectangular, water-cooled mold to produce an ingot $19 \mathrm{~mm}$ square by $63 \mathrm{~mm}$ high, weighing about $500 \mathrm{~g}$. The ingot was radiographed to locate internal porosity. In some instances, EB welding was used to repair porosity in the ingot. The casting was placed in a molybdenum frame to minimize cracking of the material during the initial rolling passes. The material was susceptible to cracking at this stage due to the coarse grain structure of the cast ingot.

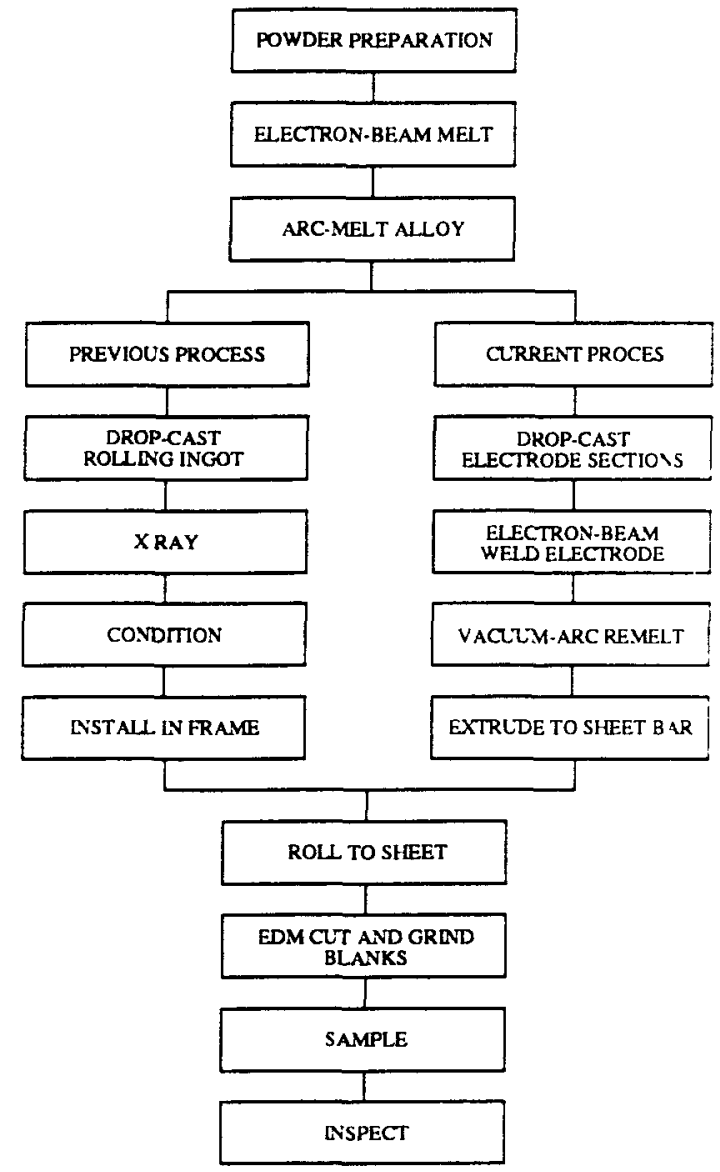

FIGURE 1. Schematic diagram of manufacturing processes for blanks.

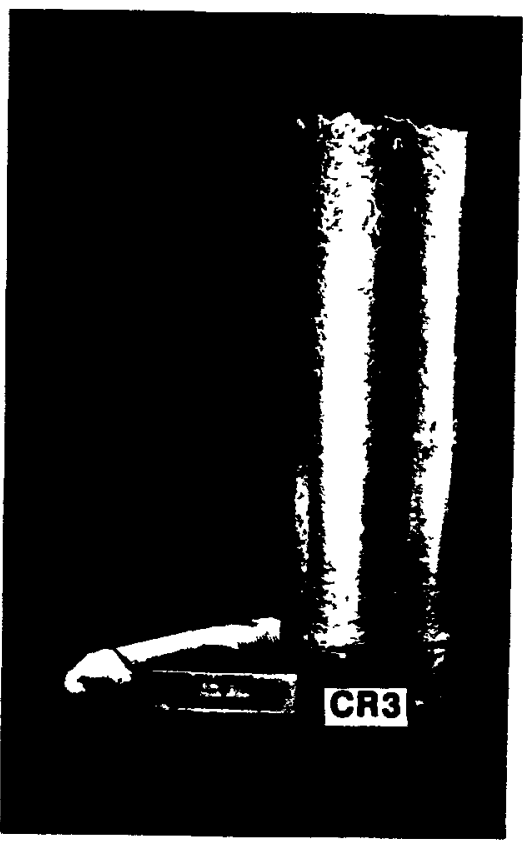

FIGURE 2. Vacuum-arc-remelted ingot and electrode stub.

In the current production process (Heestand et al. 1988), the alloy button is melted and allowed to drop into a circular mold to produce a $27-\mathrm{mm}$-diam by about 125 -mm-high ingot. These are EB welded end to end to produce an electrode of about $1.1 \mathrm{~m}$ in length. The electrode is processed by vacuum arc remelting (VAR) into a water-cooled copper mold of 63-mm diam to produce an ingot weighing about $10 \mathrm{~kg}$. The ingot is hot extruded to produce a rectangular bar that is cut into pieces suitable for rolling to sheet. These processes are described in detail below. 
The procedures for rolling sheet are similar for the two processes. The major difference is the reduced amount of cross rolling with the current manufacturing process. Machining of blanks from the rolled sheet by electrodischarge machining (EDM) and surface grinding and inspection of the finished blanks is the same for both processes. However, due to the larger ingot size, the number of samples required for chemical analysis of sheets produced using the current process is half that of the previous process.

\section{Vacuum Arc Remelting}

The VAR process is critical to the manufacturing process because it is the final melting step, and any defects in the ingot are likely to remain in the finished blanks. In the VAR process, the iridium alloy electrode is placed in a vacuum chamber, and an arc is struck between the electrode and an iridium alloy pad that is located at the bottom of a watercooled copper mold. The heat of the arc causes the molten metal to drip from the electrode and fall into a molten metal pool. As melting continues, the electrode is fed toward the pool to maintain a constant arc gap, and solidification of the ingot occurs below the molten pool. The arc gap is controlled indirectly by control of the voltage. Since the depth of the molten pool is maintained at about $25 \mathrm{~mm}$ by the continual addition of molten metal at the top of the pool and its solidification at the bottom of the pool, porosity in the ingot, unlike the drop castings, can be confined to the topmost portion of the ingot, which can be removed and remelted.

During the development process, the mold size was initially chosen as $51 \mathrm{~mm}$ diam with a 25 -mm-diam electrode. A total of 6 ingots were processed to produce about 50 blanks each. Inspection results for the blanks exhibited large variations from ingot to ingot. Ultrasonic indications above the specified limits were not found in any of the blanks from two of these ingots but were as high as $33 \%$ for another ingot. There were also variations in the surface appearance of the ingots. Some exhibited evidence that the arc between the electrode end and the molten pool was not stable and that a number of arc strikes to the sidewall of the copper mold occurred. It was determined that the 51 -mm-diam mold did not permit sufficient clearance between the mold and the electrode, a condition which was exacerbated by the limitations on the straightness of the welded electrode.

In order to produce consistent, defect-free ingots, the mold diameter was increased to $63 \mathrm{~mm}$ and a requirement established for a minimum clearance of $12 \mathrm{~mm}$ between the electrode and the mold over the entire length of the electrode travel. The increase in mold diameter, combined with an increase in the height of the ingot, increased the number of blanks from each ingot to over 100 . The arc current (dc electode negative) is maintained at $3000 \mathrm{~A}$ in order to provide sufficient heat to remelt splattered metal that solidified on the mold wall, above the level of the molten pool. Failure to do this results in a rough ingot surface and subsurface porosity. An iridium alloy ingot is shown in Figure 2, together with the remaining unmelted stub of the electrode. The surface of the ingot is generally quite smooth, except for the unmelted ring of splattered material visible at the top of the ingot, which is removed prior to subsequent processing.

\section{Extrusion}

The extrusion of the iridium alloy ingot is performed to make both the geometry and the microstructure of the material more suitable for subsequent rolling operations. The iridium alloy ingot is diamond ground to remove about $0.5 \mathrm{~mm}$ from the surface and is placed in a molybdenum can with a wall thickness of $12 \mathrm{~mm}$. The can is heated to $1700 \mathrm{~K}$ and hot extruded through a die opening of 51 by $19 \mathrm{~mm}$. The molybdenum can serves both to slow the rate of cooling the iridium during extrusion and improve lubrication through the 
formation of molybdenum trioxide. After cooling, the molybdenum is chemically removed to obtain a rectangular, iridium alloy bar of about $12 \times 38 \times 900-\mathrm{mm}$ long. This bar is cut into pieces of suitable length for rolling.

In order to develop the reliable extrusion practice, it was necessary to overcome the load limitations of the extrusion press. During the time of 25 to $30 \mathrm{~s}$ required to load the preheated material into the press and perform the extrusion, the material is cooling and increasing its resistance to mechanical deformation. If the temperature decreases to the value, at which the resistance to deformation exceeds the load capacity of the press (8.0 MN for this geometry), the extrusion will stop, and the resulting thermal stresses can crack the material. In order to avoid this, it was necessary to employ a powdered glass for additional lubrication, and use a 3 -h preheat at $1700 \mathrm{~K}$. This preheat is sufficiently high that a measurable reaction occurs between the molybdenum can and the iridium alloy ingot, and additional cleaning steps following the chemical removal of the molybdenum are necessary to remove the reaction products (Ohriner and George 1991).

\section{PRODUCT YIELDS}

The yield of blanks is summarized in Table 1 for three production campaigns. The first of these is for a portion of the production effort for the Voyager spacecraft in the middle 1970 s, the second is for the Galileo and Ulysses spacecraft in the early 1980s, and the last is for the current production for the Cassini spacecraft. The overall yield of blanks meeting all inspection criteria has increased from an average of $70 \%$ for the drop-cast ingot process to a value of $91 \%$ for the VAR ingot process. The main cause of rejection for blanks in the drop-cast process after ultrasonic indications of flaws is dye-penetrant indications of defects, which cannot be removed by reworking. An important cause for rejection of blanks in the VAR process is dimensional nonconformances, which are decreasing with continued production.

Table 1. Comparison of blank yields for different manufacturing processes

\begin{tabular}{|c|c|c|c|c|c|}
\hline \multirow{2}{*}{ Dates } & \multirow{2}{*}{ Alloy } & \multirow{2}{*}{$\begin{array}{l}\text { Ingot } \\
\text { type }\end{array}$} & \multirow{2}{*}{$\begin{array}{l}\text { Blanks } \\
\text { machined }\end{array}$} & \multicolumn{2}{|c|}{$\begin{array}{c}\text { Passing inspection } \\
(\%)\end{array}$} \\
\hline & & & & Ultrasonic & All \\
\hline $11 / 73$ to $04 / 74$ & $\mathrm{Ir}-0.3 \% \mathrm{~W}$ & Drop cast & 484 & 87 & 77 \\
\hline $01 / 81$ to $11 / 83$ & DOP-26 & Drop cast & 2265 & 84 & 69 \\
\hline $09 / 89$ to $05 / 92$ & DOP-26 & VAR & 994 & 96 & 91 \\
\hline
\end{tabular}

PRODUCT EVALUATION AND QUALITY CONTROL

The effect of the changes in the manufacturing process on the properties of the material, with respect to both subsequent fabrication and service, has been extensively evaluated. Forrest et al. (1986) found that there are slight differences in the forming behavior of blanks produced by the two processes. These differences were predicted to require only minor changes in forming tool dimensions. Manufacturing development and production of cups at the Oak Ridge Y-12 Plant have confirmed this. The effects of the manufacturing 
process on microstructure, uniaxial tensile impact ductility and crystal-lographic texture, and weldability (Ohriner et al. 1992) have been studied at Oak Ridge. Additional welding evaluations have been performed at Savannah River (Kanne, 1987). High-strain-rate biaxial testing, as well as testing of simulated fueled clads, has been performed at Los Alamos (George 1988). In each case, the product of the VAR manufacturing process showed equal or better properties than that of the drop-cast process.

All of the materials used for process development, product characterization, or production have been manufactured using the same production system used for previous production efforts and incorporate all applicable quality requirements. These include use of approved procedures, route cards, and traveler documents. Procedures are approved in accordance with established agreements, with the level of approval dependent on the type of procedural change, and the usage of the product. Other quality requirements include: (1) tagging of parts, (2) material traceability, (3) operator qualifications and certifications, and (4) surveillances and independent audits.

\section{CONCLUSIONS}

The conclusions of this process development work and blank production efforts to date are:

1. A manufacturing process for iridium alloy blanks using VAR ingots has successfully replaced the former process using drop-cast ingots.

2. The yields of finished blanks through all inspection steps have increased from 70 to over $90 \%$.

3. The properties of the material produced by the VAR process are equal to or better than those of material produced by the drop-cast process.

\section{Acknowledgments}

The author thanks W. J. Barnett (DOE-Office of Special Applications) for useful discussions of this work, M. M. Martin for compilation of process data from small ingots, R. H. Cooper and R. L. Heestand for reviewing the manuscript, K. Spence for editing, and M. L. Atchley for preparation of the manuscript. Research was sponsored by the Office of Space and Defense Power Systems, Office of Special Applications, U.S. Department of Energy, under contract DE-AC05-84OR21400 with Martin Marietta Energy Systems, Inc.

\section{References}

Braski, D. N. and A. C. Schaffhauser (1975) Production of Ir-0.3\% W Disks and Foil, ORNL-TM-4865, Martin Marietta Energy Systems, Inc., Oak Ridge Natl. Lab., Oak Ridge, Tennessee.

Forrest, M. A., J. R. McDougal, and R. W. Saylor (1986) General Purpose Heat Source (GPHS) Clad Vent Set (CVS) Formability Study, MLM-3398, EG\&G Mound Applied Technologies Inc., Miamisburg, Ohio.

George, T. G. (1988) High-Strain Rate High-Temperature Biaxial Testing of DOP-26 Iridium Alloy, LA11063, Los Alamos Natl. Lab., Los Alamos, N.M. 
Heestand, R. L., E. K. Ohriner, and T. K. Roche (1988) Advances in Iridium Alloy Processing in 1987, ORNL TM-10852, Martin Marietta Energy Systems, Inc., Oak Ridge Natl. Lab., Oak Ridge, Tennessee.

Kanne, W. R. (1987) Weldability of General Purpose Heat Source New Process Iridium, DP-1748, Westinghouse Savannah River Company, Aiken, S.C.

Ohriner, E. K. and E. P. George (1991) "Growth of Intermetallic Layers in the IridiumMolybdenum System," in J. Alloys Compounds 177, 219-227.

Ohriner, E. K., G. M Goodwin, and D. A. Frederick (1992) "Weldability of DOP-26 Iridium Alloy: Effects of Welding Gas and Alloy Composition" in Proc. Ninth Symposium on Space Nuclear Power Systems, ed. M. S. El-Genk and M. D. Hoover, Institute for Space Nuclear Studies, University of New Mexico, Albuquerque, N.M.

\section{DISCLAIMER}

This report was prepared as an account of work sponsored by an agency of the United States

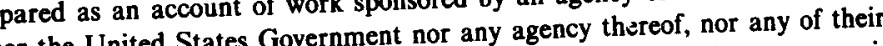
Government. Neither the United States Government nor any agency ther liability or responsiemployees, makes any warranty, express or implied, or assumes any legal liablitys, product, or bility for the accuracy, completeness, or usefulness of any information, apparatus, prods. Referprocess disclosed, or represents that its use would not infringe privately owame, trademark, ence herein to any specific commercial product, process, or ser imply its endorsement, recommanufacturer, or otherwise does not necessarily constitute or imply its chdorsereof. The views mendation, or favoring by the United States Government or any agency theflect those of the and opinions of authors expressed herein do not

United States Government or any agency thereof. 